
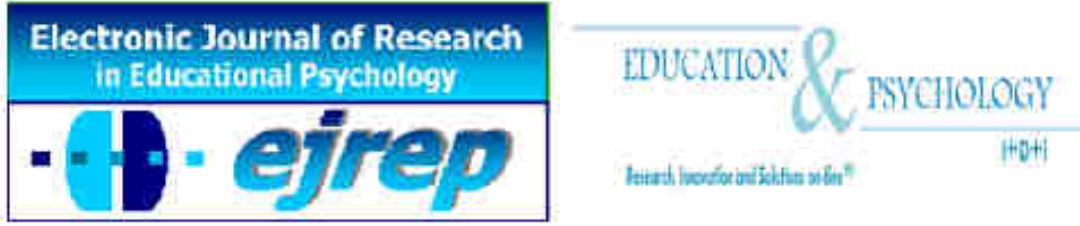

llustre Colegio Oficial de Psicología

\title{
Role of Attributional, Styles and Perceived Control in Control in Social Anxiety Among University Entrants
}

\section{Ravneet Kaur}

Department of Psychology, Punjabi University, Patiala

\section{India}

Correspondence: Ravneet Kaur, Department of Psychology, Punjabi University, Patiala. e-mail: ritubawa02@gmail.com

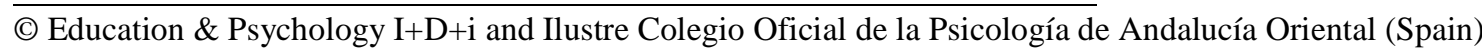




\begin{abstract}
Introduction. Social anxiety is a persistent, intense and chronic fear of being negatively judged by others as well as by themselves and being embarrassed by one's own actions. Attributional styles is known as the way an individual explains positive and negative events in life and it has an important bearing on her well being, motivation and performance. Perceived control refers to the belief that one can determine one's own internal state and behavior, influence one's environment, and/or bring about desired outcomes. Socially anxious individuals feel that they lack control over the events affecting them. The present study is carried out to check the relationship of social anxiety with attributional style and perceived control.
\end{abstract}

Method. Liebowitz Social Anxiety Scale, Attributional Style Assessment Testing-I and Perceived Control Scale were administered on 200 female participants from Punjabi University, Patiala. Using correlational design, Pearson's bivariate correlations were performed.

Results. The findings showed that there was positive correlation between ability attribution for failure and social anxiety, and negative correlation was found between effort attribution for failure and social anxiety. There was also a negative correlation between interpersonal control, the dimension of perceived control and social anxiety. Regression analysis showed that ability attribution for failure and interpersonal control are significantly predictor of social anxiety.

Discussion. The present study was conducted on assessing the relation of social anxiety with attibutional style and perceived control among university entrants. The findings revealed that freshers with high level of social anxiety showed dysfunctional Attributional style and low perceived control than those low on social anxiety. Implications of the findings have been discussed.

Keywords: social anxiety, attributional styles, perceived control, university entrant 


\section{Resumen}

Introducción. La ansiedad social es un miedo persistente, intenso y crónico de ser juzgado negativamente por los demás, así como por ellos mismos y ser avergonzado por las propias acciones. Los estilos de atribución se conocen como la forma en que un individuo explica los acontecimientos positivos y negativos en la vida y tiene una influencia importante en su bienestar, motivación y rendimiento. El control percibido se refiere a la creencia de que uno puede determinar el propio estado interno y comportamiento, influir en el medio ambiente y lograr los resultados deseados. Las personas socialmente ansiosas sienten que carecen de control sobre los eventos que las afectan. El presente estudio se realizó para verificar la relación de la ansiedad social con el estilo atribucional y el control percibido.

Método. La escala de ansiedad social de Liebowitz, la prueba de evaluación de estilo atribucional y la escala de control percibida se administraron a 200 mujeres participantes de Punjabi University, Patiala. Utilizando diseño correlacional, se efectuaron análisis de correlaciones bivariadas de Pearson.

Resultados. Los hallazgos mostraron que hubo una correlación positiva entre la atribución de capacidad para el fracaso y la ansiedad social, y se encontró una correlación negativa entre la atribución del esfuerzo por fracaso y la ansiedad social. También hubo una correlación negativa entre el control interpersonal, la dimensión del control percibido y la ansiedad social. El análisis de regresión mostró que la atribución de capacidad para el fracaso y el control interpersonal son significativamente predictores de ansiedad social.

Discusión. El presente estudio se realizó para evaluar la relación de la ansiedad social con el estilo attibucional y el control percibido entre los participantes universitarios. Los hallazgos revelaron que los freshers con alto nivel de ansiedad social mostraron un estilo atribucional disfuncional y un bajo control percibido que aquellos con bajo nivel de ansiedad social. Se han discutido las implicaciones de los hallazgos.

Palabras clave: ansiedad social, estilos de atribución, control percibido, ingreso universitario 


\section{Introduction}

Social anxiety is a specific form of anxiety. It is a debilitating and chronic illness known as a marked and persistent fear of one or more social and performance situations involving exposure to unfamiliar people or possible scrutiny or judgment by others (Schneier, 2006 \& Furmark, 2002). It is an emotion which is characterized by a discomfort or a fear when an individual is in a social interaction that includes a concern of being judged or evaluated by others (Jacobs, 2012). It is generally characterized by an intense fear of what other people are thinking about them (specially fear of embarrassment or humiliation, criticism and rejection), which results in insecurity among them and feeling not good enough for other people, and/or the assumption that peer group will automatically reject them (Garcia-Lopez, 2013). The desire to annoy no one and to harm no one along with physical symptoms like sweating, blushing, palpitation, nausea and difficulty in talking, can equally well be the sign of anxious disposition. All these can either lead an individual to avoid many social situations or they endure these situations with extreme anxiety or distress (Liebowitz, 1999).

People who have social anxiety specifically find agonizing the potential risk of performing scantily in front of others and show overt signs of nervousness with resultant embarrassment and humiliation. They have fear of negative evaluation by others, anticipatory social anxiety, inhibition, withdrawal, and avoidance of social contacts. They care about how others react to them and ultimately want to make a positive impression. In response to these social concerns, socially anxious individuals devote considerable self-regulatory resources (e.g., attention, physical stamina, and impulse control) for fearing, controlling, and avoiding anxious thoughts, feelings, and behaviors (Kashdan \& Steger, 2006; Spurr \& Stopa, 2002). Lifetime prevalence ranges from 2.8 to $13 \%$ in epidemiological studies (Kessler et al., 2007). The onset of social anxiety almost occurs in childhood or in the middle of teen age; onset after the age of 25 is unusual. Females are more prone to social anxiety disorder because generally males get more care and are able to seek help for their disorder when compared to females in Indian society. Moreover, female health is normally ignored in a developing country like India. Social phobia is of major concern to society because of high rate of co morbidity with other mental health problems such as major depression and substance abuse. Another reason is the loss to the larger 
society of the gifts and talents that these patients possess. Thereby, early diagnosis of this condition and the role of family and school in bringing up the child for treatment are imperative and need to be strengthened (Chhabra et al., 2009).

The effect of social anxiety is widespread, i.e., it is not limited to academic environment but spreads to other areas viz., social and personal. The fear of performing inadequately in front of others and fear of being negatively judged by others is the central focus of people who are high on social anxiety. They are so much over occupied with such fear that the other important issues that require focus and concentration go into the background when the actual situation of social performance come, the result is failure because the whole energy was focused on fear, not on the efforts required for performance. The resultant embarrassment and humiliation further maintains the level of social anxiety in such individuals. Keeping the detrimental effects of social anxiety in mind, the present study was carried out to assess the role of two very important variables namely attributional styles and perceived control in social anxiety among university entrants. Many studies have shown that both internal and environmental factors lead to social anxiety. Therefore, the present research has carried out to check the role of attributional style and perceived control in social anxiety that predispose university entrants to cope up with this positively and negatively.

\section{Attributional Style}

Attributional style (AS) is considered as a fundamental factor in social anxiety in particular, specially attributional style of failure (stable and internal). Attributional explanations are practical and rooted in the social system. In fact all human social behaviors follow some form of mediating causal analysis. Attributional style was introduced in Abramson, Seligman, and Teasdale's reformulated model of learned helplessness (1978) to account for people's individual differences in helplessness upon perceiving non-contingency between behavior and outcomes. According to their theory, individuals who habitually explained bad events in terms of stable, global and internal reasons rather than unstable, specific and external ones are more likely to face depression. 
Anderson (1999) talked about attribution in terms of causal explanation that folks offer regarding a variety of interpersonal and intrapersonal events and incidents in their lives. Stajkovic and Sommer (2000) explained attribution as how a person explains the causes of his or her own or another's behavioral outcomes. An explanatory style is a tendency to explain events and incidents in a particular approach. It is most usually based on three dimensions: internality (level of personal responsibility), stability (temporary versus long-lasting causes) and globality (specific versus generalized causes) (Peterson and Chang 2003). According to Weiner (1986) the following factors come under the three dimensions of attribution:

1) Effort: it is internal, unstable and controllable. Effort can be enhanced with hard work.

2) Task Difficulty: it is external, unstable and uncontrollable. It is out of hands of an individual.

3) Luck: it is external, unstable and uncontrollable.

4) Ability: it is internal, stable and uncontrollable. The person is born with some abilities or calibers, it cannot be changed with time.

Seligman $(1991,2011)$ posits that an optimistic explanatory style increases chances of success in many areas because it leads to greater determination and resilience. Research studies have shown that an optimistic explanatory style leads to success in areas such as sales performance (Corr \& Gray, 1995; Corr \& Gray, 1996a; Seligman \& Schulman, 1986), education (Peterson \& Barrett, 1987) and sport (Gordon, 2008; Martin-Krumm et al., 2003; Seligman et al., 1990; Sellers \& Peterson, 1993). Research by Taylor \& Wald (2003) has also been carried out on attributional style of socially anxious individuals and that of those suffering from panic disorder. It has been reported that socially anxious individuals make less internal attributions for positive social events and more stable attributions for negative social situations than those suffering from panic disorder. There was also a trend for the socially anxious group to make more internal attributions for negative social situations. Li, Qiu, \& Wang (2001) also found that stable and global attributions about bad events predict depression, anxiety, obsession and compulsion. These attributional styles are associated with low self-efficacy, low sales performance, and high turnover intention among Taiwanese insurance salespeople in underselling and rejection situations (Chung, 2002). Studies (Clarke \& Singh, 2005; Yu et al., 
2005) have found that pessimistic AS is related to low performance at school, sports and workplace, and low subjective well-being.

Feelings of competence and perception of control can help relieve an individual's emotional distress. This can also lead an individual in making attempts to solve stressful difficulty. It means that the sense of control is vital for one's well-being. The tendency of socially anxious individuals to perceive less control over the situations affecting them reinforces their social anxiety. A description of perceived control, the second variable of the present study is as follows.

\section{Perceived Control}

Perceived control contributes a vital role for health across childhood to old age. It is known as the belief that one has the ability to make a difference in the course or the consequences of some event or experience which become helpful in dealing with stressors (Infurna et al., 2013). It is the subjectively judged capacity to influence life events and clearly linked to better health and survival among older adults (Chipperfield, Campbell, \& Perry, 2004; Schulz \& Heckhausen, 1999).

Perceived control can be a key factor in living longer. It is also known as locus of control, the confidence we have in our ability to control our own lives in maintaining a healthy lifestyle and avoiding high-risk activities that can cause medical problems later in life (Vitelli, 2013). Starting from adolescence, perceived control forms ability to develop good health habits that can prevent future problems. Research (Tate, Patterson, Nagel, Anderson, \& Brown, 2007) has shown that higher perceived control in adolescents is linked to lower psychological stress and anxiety, better cardiovascular health, lower inflammation, and reduced obesity by the time those adolescents reach young adulthood. The healthy decisions that come from perceived control can lead to favorable outcomes much later in life as well.

Tangney, Baumeister \& Boone (2004) have found that people who see themselves in charge of their lives are more likely to take active steps to ensure they remain healthy and more likely to have internal attributional style for their actions. That includes healthy behaviours such 
as eating sensibly, exercise, and complying with medical treatment. Perceived control may also influence how we regulate emotions, anxiety and handle stress as well as helping us develop social support networks, especially during crises that can help us cope more effectively.

Furthermore, perceived control over one's environment that is attributional style has been consistently linked to prevalence of alcohol use (Adalbjarnardottir \& Rafnsson, 2001). And age is going to play a factor in how much control we think we have over our lives. According to longitudinal studies, perceived control increases when we are young adults, remains fairly stable throughout middle age, and starts to decline once we reach our golden years. Unfortunately, it is in old age when perceived control becomes especially important in protecting us from the various medical problems that grow worse with time (Tate, Patterson, Nagel, Anderson, \& Brown, 2007). Lachman \& Firth (2004) have found that those with a higher sense of control had greater life satisfaction and a more optimistic view of adulthood; they reported that things were going well and expected them to either stay that way or even to get better in the future. They also have examined possible affective, behavioral, motivational, and physiological mechanisms, including social anxiety, effort, compensatory strategies, and physical activity, that link control beliefs and outcomes. For example, in the health domain, they found that those who have a higher sense of control are more likely to exercise regularly and also to have better mental and physical health.

Socially anxious individuals have also been reported (Cain, 2009) to maladaptively trying to satisfy their communal strivings. They appeared to be trying to avoid rejection in social situations by employing self-protective interpersonal motives that are cold and socially avoidant. The review of literature (Hofmann, 2005) reveals that "costly" social situations are anxiety provoking in part because socially anxious individuals perceive their anxiety symptoms as being out of control. On the same lines, other research studies (Barlow, 2002) have reported that high trait negative affect, low trait positive affect, low perceived control and safety behaviors are the factors associated with the development and maintenance of social anxiety. Thus, feeling lack of control over what happens around an individual may result in fear of such situations further leading to social anxiety. 


\section{Objectives:}

1) To study the relationship, if any, between social anxiety and attributional styles.

2) To study the relationship, if any, between social anxiety and attributional styles in terms of subscales likewise, attribution style of failure to ability/personality traits, attribution style of failure to effort/strategy, attribution style of failure to $\operatorname{mood} /$ circumstances, attribution style of success to ability/personality traits, attribution style of success to effort/strategy and attribution style of success to mood/circumstances with social anxiety.

3) To explore the relationship, if any, between social anxiety and perceived control

4) To explore the relationship, if any, between social anxiety and in terms of perceived control subscales likewise, personal control, Interpersonal control in social anxiety and socio-political control in social anxiety.

Hypotheses: On the basis of review of literature, 9 hypotheses were made:

1) Attribution of failure to ability/personality traits would be positively related to social anxiety.

2) There would be negative correlation between attribution of failure to effort/strategy and social anxiety.

3) Attribution of failure to mood/circumstances would be negatively related to social anxiety.

4) There would be negative correlation between attribution of success to ability/personality traits and social anxiety.

5) Attribution of success to effort/strategy would be negatively related to social anxiety.

6) There would be positive correlation between attribution of success to $\operatorname{mood} /$ circumstances and social anxiety.

7) There would be negative correlation between personal control and social anxiety. 
8) Interpersonal control would be negatively related to social anxiety.

9) There would be negative correlation between socio-political control and social anxiety.

\section{Method}

\section{Participants}

A total of 200 female university entrants were taken from different teaching departments of Punjabi University, Patiala. All participants were students of first year of their PostGraduation course. The age range of the participants was 19 to 24 years. Prior consent was taken from the participants.

\section{Instruments}

Liebowitz Social Anxiety Scale (LSAS) by Liebowitz (1999) was used to assess social anxiety. The scale is composed of 24 items divided into 2 subscales; 13 pertaining performance anxiety and 11 concerning to social situations. All the 24 statements are rated on fear and avoidance experienced by the respondents in the past few weeks using 0-3 Likert-type scale. The internal scale consistency reliability at baseline is 0.94 and the mean item-to-total scale correlation is 0.47 . The Cronbach alpha obtained for the fear/anxiety domain was 0.88 and for the avoidance domain was 0.87 .

Attributional Style Assessment Testing (ASAT-I) by Anderson (1982) was used to assess Attributional styles. It consists of 20 situations out of which 10 situations are related to failure and rest10 are related to success. All the statements are rated on 6 likert-point scale. These 6 likert-points are: ability, effort, strategy, mood, personality traits and circumstances. Further, these 6 points are combined into 3 subscales: ability/personality traits, effort/strategy and mood/circumstances. For this scale, the reliability is modest, ranging from .51 to .60 .

Perceived Control Scale by Paulhus and Christie (1983) was used to assess perceived control. It consists of 30 items divided into 3 subscales: personal control, interpersonal control and socio-political control as well as their interaction. All the items are rated on 7 likert-point 
scale ranging from disagree to agree. In general, internal consistency of the scale is quite good and Cronbach's alpha found over .85 and it also demonstrated good concurrent and predictive validity.

\section{Procedure}

The sample was selected through opportunity sampling. The appropriate conditions where proper light, ventilation and accurate room temperature were maintained for participants to fill the questionnaires without any distraction. Rapport was built and participants were given the Social Anxiety Scale, Attributional style Assessment Testing and Perceived Control Scale and about 60 minutes time was given to complete the scales. After the completion of those scales all participants were thanked for their participation and effort in research.

\section{Data Analysis}

Correlational design was used and Pearson Product Moment coefficient was computed. Further, to assess the relative contribution of the independent variables, viz., attributional style and perceived control separately as well as conjointly, in explaining the variance of dependent variable of social anxiety, stepwise multiple regression analysis was applied, with SPSS v. 20 program. Correlation coefficient was conducted to see the relationship among variables, and 3 of the hypotheses came significant.The data were also analyzed with regression to see the effect of social anxiety on attributional style and perceived control and it has seen that social anxiety contributed to some of the subscales of attributional styles an perceived control.

\section{Results}

Research was conducted on university entrants to see the relationship of social anxiety with attributional styles and perceived control. It was seen that who is high on social anxiety was high on ability attribution for failure and result came out was $[r=.33, p<.01]$, it means that there is significant positive correlation between these two. Second hypothesis which came out significant is that there is negative correlation between social anxiety and efforet attribution for failure and correlation coefficient was $[r=-.22, p<.01]$. Third hypothesis that there is negative correlation 
between social anxiety and interpersonal control and correlation coefficient came was $[r=-.25, p$ $<.01]$. The results are shown in table 1 .

Table 1. Correlation Matrix

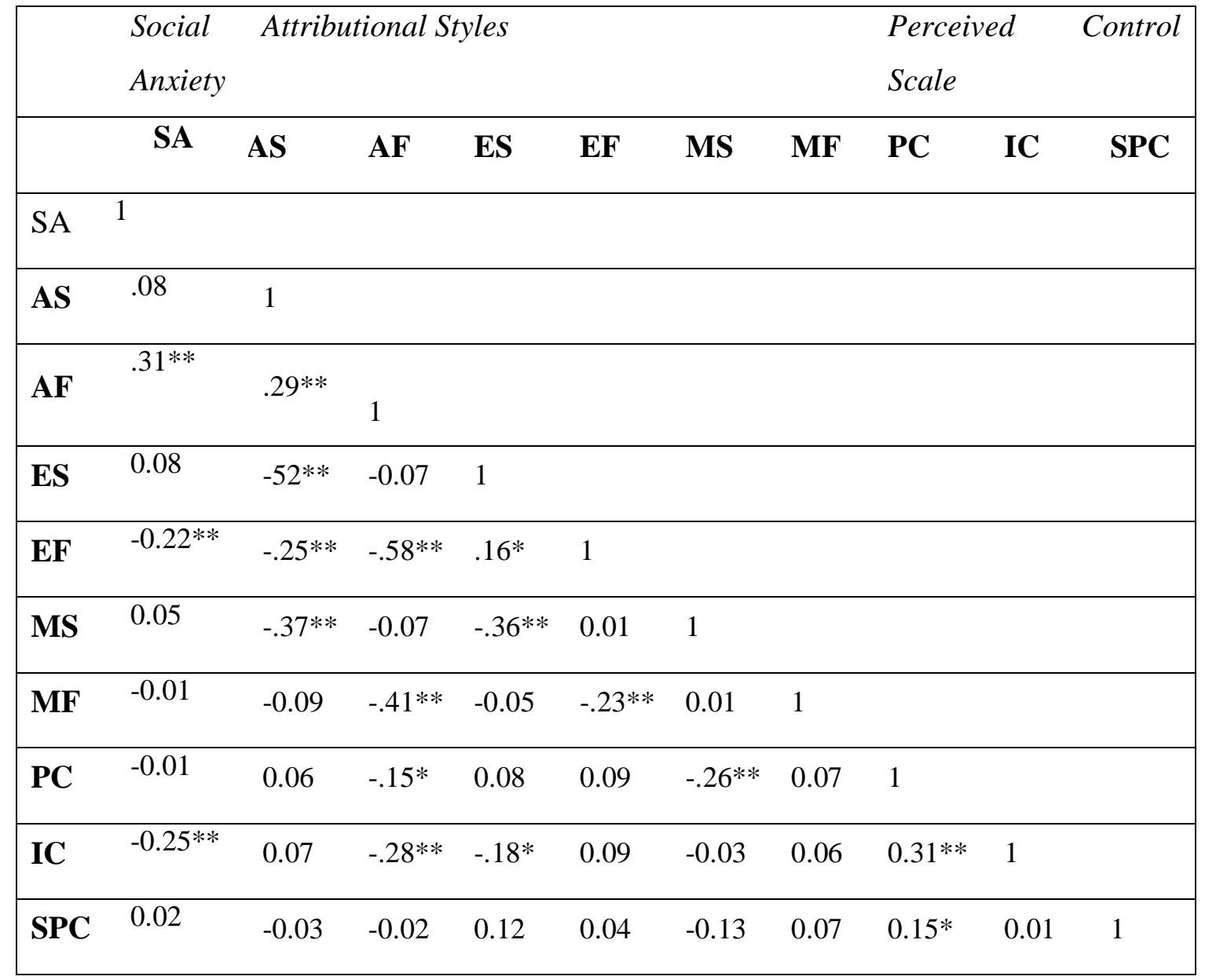

Note: $\mathrm{AS}=$ Ability Attribution for Success, AF= Ability Attribution for Failure, ES= Effort Attribution for Success, $\mathrm{EF}=$ Effort Attribution for failure, $\mathrm{MS}=$ Mood Attribution for Success, MF= Mood Attribution for Failure, $\mathrm{PC}=$ Personal Control, IC=Interpersonal Control, SPC= Socio-political Control, SA= Social Anxiety.

$* p<.05 ; * *<.01$

\section{Regression Analyses}


Regression analysis was conducted to found out the predictors of social anxiety shown in table 2. For regression analysis, all predictor variables were entered. In each step of the analysis the predictors were regressed on social anxiety accordingly. Regression analyses revealed that $12 \%$ of the variance in social anxiety was due to ability attribution for failure and interpersonal control (Table II). The variation in social anxiety contributed by ability attribution of failure was $9 \%$ and beta value showed that ability attribution to failure has positive significant effect on social anxiety $\left.\left[R^{2}=.09, \beta=.25, p<.000\right]\right)$. The results of regression revealed that interpersonal control accounted 3\% variance in social anxiety and the beta value showed that interpersonal control has negative significant effect on social anxiety $\left[R^{2}=.03, \beta=-.18, p<.000\right]$.

Table 2. Summary of Regression Analysis

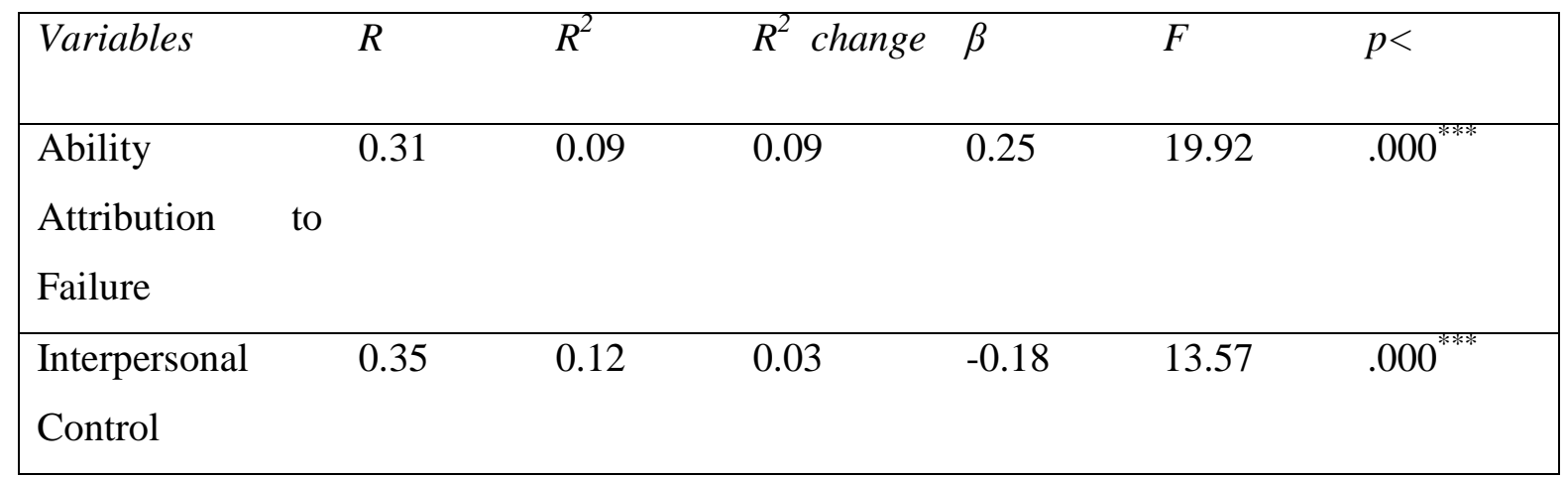

Note: $* p<.05 ; * * p<.01 ; * * * \mathrm{p}<.001$.

Criterion Variable: Social Anxiety

Predictor Variables: Ability Attribution for Failure, Interpersonal Control

\section{Discussion}

The results support the previous literature that ability attribution to failure play significant positive role in enhancing social anxiety and effort attributional style to failure helps to reduce 
social anxiety. Likewise, findings of this study have shown that individuals with high interpersonal control have low level of social anxiety.

Attributional style is a significant predictor of social anxiety. A higher tendency to blame oneself for negative events in life leads to negative affect, self-blame, low perceived control, low self-esteem and social anxiety (Davidson, Hughes, George, \& Blazer, 1994; Bandura,1997). The findings of the present study show that social anxiety has significant positive correlation with ability attribution for failure and ability attribution for failure has significantly predicted social anxiety. This finding is in support of the first hypothesis. The participants, who attributed their failure and negative events to their abilities and personality traits, were also high on social anxiety. The finding has similar results as reported by Coles et al. (2001) that individuals with social anxiety adopted ever more internal, stable, and global attributions for social events as result their level of anxiety increased. The opposite was true for non-socially anxious individuals, who took a self-serving bias in high anxiety situations, in which they viewed the situation as increasingly due to external, unstable, and specific causes which help them to reduced their social anxiety level. Lundh and Sperling (2002) found that social anxiety was highly correlated specially with being negatively evaluated by others as compared to generally alarming or distressing social events. When more literature is examined then found Alfano, Joiner, and Perry (1994), in their research study, also came to this conclusion that there is a significant association between social anxiety and global, stable, and internal attributions, as well as negative expectations about social events.

Another noteworthy finding of the present study is the significant negative correlation between attribution of failure of effort and strategy and social anxiety, thus suggesting that when individuals attributed their failure to effort and strategy, social anxiety was low. Though, effort and strategy are the internal factors, they are controllable, unstable and specific too. It means that when individuals attribute their failure outcome to effort and strategy, they believe that they have a sense of control and they can change their failure outcome into success outcome in future. Thus, the participants who blamed lack of effort and poor strategy as reasons for their failure did not lose hope of future success as they were sure they could make more efforts and use better strategies the next time. This is because effort and strategy are the unstable dimensions of 
attributional style and these are the factors which are also controllable. So, the participants who attributed failure to effort and strategy reported less social anxiety. The finding gets support and is in agreement with Coles, Turk, Heimberg, and Fresco (2001), who demonstrated that when socially anxious people recalled high or medium anxious social situations, their attributions for their performance became more internal and stable while control participants attributed highly anxious situations less to internal and stable factors. Additionally, one more study has supported an association between social anxiety and controllable attributions for both negative and positive social events (Bruch and Belkin, 2001). The belief that they can change their future positively by putting efforts and using new strategies lower the level of an individuals' social anxiety. This is in contrast to those who do not believe in the fact that they can do something to change the outcome.

As hypothesized in the present study, interpersonal control has significant inverse correlation with social anxiety and interpersonal control significantly contributed to social anxiety. It means that participants who were high on interpersonal control showed low level of social anxiety. Interpersonal control indicates that person has good social network and he/she cooperates to help each other. The person can make friends in new environment very easily. She has no hesitation in social situations and no fear of presenting herself in front of others. That is why people high on interpersonal control showed less signs of social anxiety. Research is also in agreement with this finding which include the examination of interpersonal interactions of socially anxious people with significant others and strangers (Alden, 2001; Alden and Taylor, 2004). In a social interaction when socially anxious students ask question about another person's experiences and attitude, they are too fearful to communicate anything meaningful about themselves (Alden, 2001).

The findings of the present research have significant implications in the area of counselling of university/college students. Study of social anxiety is necessary because barrier of self-presentation affects all the domains of an individual's life, such as social, academic and occupational. It was thought imperative to explore the extent to which the attributional style and perceived control play a role in social anxiety among university entrants. Socially anxious individuals hold themselves responsible for everything that goes wrong in their lives. On the 
contrary, things that go right are externalized. Such a pattern of attributions adopted by socially anxious university entrants keep them rotating in the vicious cycle of self defeating belief. Socially anxious individuals doubt their abilities, put less effort, and focus on failure which further strengthens their fear of facing people and social situations. Their belief that things are out of their control aggravates the problem further. Females especially from rural background are more prone to social anxiety because they do not get open environment where they can learn how to deal with outer world. So, the university entrants who are socially anxious especially females, can be helped out of their problem. In order to make dysfunctional attributional style more functional, Reattribution Training can be designed and used with such students. With the help of simple feedback, reattribution training aims at making pejorative attributions nonpejorative. Despite the important findings and implication of the present research, there are some limitations which are as follows:

1) The study has not included any variables pertaining to social environment, such as economic status due to time limit constrain, because it can make the analysis lengthier and time taking.

2) The study has not drawn a comparison between university entrants from rural and urban background because students from rural area are more submissive and suppressed than students from urban areas.

Following are some suggestions for future research:

1) Future research should draw a comparison of male and female socially anxious participants to approach the diverse population and better results.

2) Future research should also focus on differentiating between social anxiety levels of university entrants and that of second year students to know the difference of university exposure.

3) Future research can also take into consideration the effect of family environment and parent-child relationship to establish the link of these variables with social anxiety.

4) Future research should also focus on application of therapeutic techniques (e.g., Reattributional Training) for social anxiety, so that this issue can be addressed properly and dealt in more sensitive way to reduce the chances of social anxiety among university entrants. In this way they can explore their talent in more healthy and positive way. 


\section{References}

Abramson, L. Y., Seligman, M. E. P., \& Teasdale, J. (1978). Learned helplessness in humans: Critique and reformulation. Journal of Abnormal Psychology, 87, 49-74. http://dx.doi.org/10.1037/0021-843X.87.1.49

Adalbjarnardottir, S., \& Rafnsson, F. D. (2001). Perceived control in adolescent substance use: Concurrent and longitudinal analyses. Psychology of Addictive Behaviors, 15, 25-32. http://dx.doi.org/10.1037.0893-164X.15.1.25

Alden, L. E. (2001). Interpersonal perspectives on social phobia. In: Crozier, R. \& Alden, L.E. (Eds.). The International Handbook of Social Anxiety. London, UK: Wiley \& Sons.

Alden, L. E., \& Taylor, C.T. (2004).Interpersonal processes in social phobia. Clinical Psychology Review, 24, 857-882. http://dx.doi.org/10.1016/j.cpr.2004.07.006

Alfano, M. S., Joiner, T. E., Perry, M., \& Metalsky, G.I. (1994). Attributional style: A mediator of the shyness-depression relationship? Journal of Research in Personality, 28, 287-300. http://dx.doi.org/10.1006/jrpe.1994.1021

Anderson, C. A. (1999). Attributional Style, Depression, and Loneliness: A Cross-Cultural Comparison of American and Chinese Students. Personality and Social Psychology Bulletin, 25, 482-499. http://dx.doi.org/10.1177/0146167299025004007

Anderson, C. A., Krull, D. S., \& Weiner, B. (1996). Explanations: Processes and consequences. In E.T. Higgins \& A.W. Kruglanski (Eds.). Social psychology: Handbook of basic principles (pp. 271-296). New York: Guilford.

Barlow, D. H. (2002). Anxiety and its disorders: The nature and treatment of anxiety and panic $\left(2^{\text {nd }}\right.$ ed.). New York: Guilford Press.

Bandura, A. (1997). Self-efficacy and health behaviour. In A. Baum, S. Newman, J. Wienman. R. West, \& C. McManus (Eds.). Cambridge handbook of psychology, health and medicine (pp. 160-162). Cambridge: Cambridge University Press.

Bruch, M. A., \& Belkin, D. K. (2001). Attributional style in shyness and depression: Shared and specific maladaptive patterns. Cognitive Therapy and Research, 25, 247-259.

Cain, N. M. (2009). Interpersonal pathoplasticity in social phobia: A clinical replication. Pennsylvania: College of the Liberal Arts. 
Chhabra, V., Bhatia, M.S., Gupta, S., Kumar, P. and Srivastava, S. (2009). Psychiatric Society Prevalence of Social Phobia in school-going adolescents in an urban area. Delhi Psychiatry Journal Vol. 12, No.1, 18-25.

Chipperfield, J. G., Campbell, D. W., \& Perry, R. P. (2004). Stability in perceived control: implications for health among very old community-dwelling adults. Journal of aging and health, 16, 116-147. http://dx.doi.org/10.1177/0898264303260447

Chung, Y. Y. (2002). Scale development and evaluation under selling and rejection situations for insurance salespeople. Published doctoral dissertation, National Chiao Tung University, Taiwan.

Clarke, D., \& Singh, R. (2005). The influence of pessimistic explanatory style on the relation between stressful life events and hospital doctors' psychological distress. Social Behavior and Personality, 33, 259-272. http://dx.doi.org/10.2224/sbp.2005.33.3.259

Coles, M. E., Turk, C. L., Heimberg, R. G., \& Fresco, D. M. (2001). Effects of varying levels of anxiety within social situations: Relationship to memory perspective and attributions in social phobia. Behaviour Research and Therapy, 39, 651-665. http://dx.doi.org/10.1016/S0005-7967(00)00035-8

Corr, P.J., \& Gray. J.A. (1995). Attributional style, socialization and cognitive ability as predictors of sales success: A predictive validity study. Personality and Individual Differences, 18, 241-252. http://dx.doi.org/10.1016/0191-8869(94)00153-J

Corr, P.J., \& Gray. J.A. (1996). Attributional style as a personality factor in insurance sales performance in the UK. Journal of Occupational and Organizational Psychology, 69, 83-87. http://dx.doi.org/10.1111/j.2044-8325.1996.tb00601.x

Davidson, R.J., Marshall, J.R., Tomarken, A.J., \& Henriques, J.B. (2000). While a phobic waits: Regional brain electrical and autonomic activity in social phobics during anticipation of public speaking. Biological Psychiatry, 47, 85-95. http://dx.doi.org/10.1016/S0006-3223(99)00222-X

Doherty, W.J. (1981). Cognitive processes in intimate conflict: I extending attribution theory. The American Journal of Family Therapy, 9, 5-13. http://dx.doi.org/10.1080/01926188108250380 
Role of Attributional, Styles and Perceived Control in Control in Social Anxiety Among University Entrants

Fincham, F.D. \& Bradbury, T.N. (1992). Assessing attributions in marriage: The Relationship Attribution Measure. Journal of Personality and Social Psychology, 62, 457-468. http://dx.doi.org/10.1037/0022-3514.62.3.457

Furmark, T. (2002). Social phobia: overview of community surveys. Acta Psychiatrica Scandinavica,105: 84-93. http://dx.doi.org/10.1034/j.1600-044702002.1r103.x

Garcia-Lopez, L. J. (2013). Treating...social anxiety disorder. Madrid: Piramide.

Gordon, R. A. (2008). Attributional style and athletic performance: Strategic optimism and defensive pessimism. Psychology of Sport and Exercise, 9, 336-350. http://dx.doi.org/10.1016/jpsychsport.2007.04.007

Harre, R. (1981). Rituals, rethoric and social cognitions. In J. P. Forgas (Ed). Social Cognition. London: Academic Press.

Heider, F. (1958). The psychology of interpersonal relations. New York: John Wiley \& Sons.

Hofmann, S.G. (2005). Perception of control over anxiety mediates the relation between catastrophic thinking and social anxiety in social phobia. Behaviour Research and Therapy, 43, 885-895. http://dx.doi.org/10.1016/j.brat.2004.07.002

Infurna, F. J., Ram, N. \& Gerstorf, D. (2013). Level and change in perceived control predict 19-year mortality: Findings from the Americans' changing lives study. Developmental Psychology, 49, 1833-1847. http://dx.doi.org/10.1037/a0031041

Jacobs, A. M. (2012). Social anxiety Disorder and Social Phobia. Retrieved 14 November 2012. http://www.socialanxietysupport.com/disorder/

Jones, E. E. (1990). Interpersonal Perception. New York: Freeman and Co.

Kashdan, T. B., \& Steger, M. F. (2006). Expanding the topography of social anxiety: An experience sampling assessment of positive emotions and events, and emotion suppression. Psychological Science, 17, 120-128. http://dx.doi.org/10.1111/j.14679280.2006.01674.x

Kelley, H. H. (1972). Causal schemata and the attribution process. New York: General Learning Press.

Kessler, R. C., Amminger, G. P., Aguilar-Gaxiola, S., Alonso, J., Lee, S., \& Üstün, T.B. (2007). Age of onset of mental disorders: a review of recent literature. Current Opinion in Psychiatry, 20, 359-364. http://dx.doi.org/10.1097/YCO.0b013e32816ebc8c 
Lachman, M. E., \& Firth, K. M. (2004). The adaptive value of feeling in control during midlife. In O.G. Brim, C.D. Ryff, \& R. Kessler (Eds.), How healthy are we?: A national study of well-being at midlife (pp. 320-349). Chicago: University of Chicago.

Langer, E.J. (1983). The psychology of control. Beverly Hills, CA: Sage Publications.

Li, Z., Qiu, B., \& Wang, J. (2001). Attributional style and its correlation with mental health in adolescents. Chinese Mental Health Journal, 15, 6-8.

Liebowitz, J. (1999). The knowledge management handbook, Boca Raton, FL: CRC Press.

Martin-Krumm, C.P., Sarrazin, P.G., Peterson, C., \& Famose, J.P. (2003). Explanatory style and resilience after sports failure. Personality and Individual Differences, 35, 16851695. http://dx.doi.org/10.1016/S0191-8869(02)00390-2

Martinko, M. J. \& Gardner, W. L. (1982). Learned helplessness: An alternative explanation for performance deficits. Academic Management Review, 7, 733-739. http://dx.doi.org/10.5465/AMR.1982.4285559

Peterson, C., \& Barrett, L.C. (1987). Explanatory style and academic performance among university freshmen. Journal of Personality and Social Psychology, 53, 603-607.

Peterson, C., \& Chang, E. C. (2003). Optimism and flourishing. In C.L.M. Keyes \& J. Haidt (Eds.), Flourishing: Positive psychology and the life well-lived (pp. 55-79). Washington, DC: American Psychological Association. http://dx.doi.org/10.1037/10594-003

Schneier, F. R. (2006). Social anxiety disorder. Journal of Medicine, 355, 1029-36. http://dx.doi.org/10.1056/NEJMcp060145

Schneider, D. J., Hastorf, A.H., \& Ellsworth, P.C. (1982). Person perception ( $2^{\text {nd }}$ ed.). Reading, MA: Addison-Wesley.

Seligman, M. E. P. (1990). Learned optimism, New York: Pocket books.

Seligman, M.E.P. (2011). Recovering from failure: Building resilience. Harvard Business Review, 89, 100-106.

Seligman, M.E.P., Nolen-Hoeksema, S., Thornton, N., \& Thornton, K.M. (1990). Explanatory style as a mechanism of disappointing athletic performance. Psychological Science, $\quad 1, \quad$ 143-146. $\quad$ http://dx.doi.org/10.1111/j.14679280.1990.tb00084.x 
Seligman, M.E.P., \& Schulman, P. (1986). Explanatory style as a predictor of productivity and quitting among life insurance sales agents. Journal of Personality and Social Psychology, 50, 832-838. http://dx.doi.org/10.1037/0022-3514.50.4.832

Sellers, R.M., \& Peterson, C. (1993). Explanatory style and coping with controllable events by student-athletes. Cognition and Emotion, 7, 431-441. http://dx.doi.org/10.1080/02699939308409197

Skinner, E. A. (1995). Perceived control, motivation, and coping. Newbury Park, CA: Sage Publications.

Spurr, J. M., \& Stopa, L. (2002). Self-focused attention in social phobia and social anxiety. Clinical Psychology Review, 22, 947-975. http://dx.doi.org/10.1016/S0272$\underline{7358(02) 00107-1}$

Stajkovic, A. D., \& Sommer, S. (2000). Self-efficacy and causal attributions: Direct and reciprocal links. Journal of Applied Social Psychology, 30, 707-737. http://dx.doi.org/10.1111/j.1559-1816.2000.tb02820.x

Tangney, J. P., Baumeister, R. F., \& Boone, A. L. (2004). High self-control predicts good adjustment, less pathology, better grades, and interpersonal success. Journal of Personality, 72, 271-322. http://dx.doi.org/10.1111/j.0022-3506.2004.00263.x

Tate, S. R., Patterson, K. A., Nagel, B. J., Anderson, K. G., \& Brown, S. A. (2007). Addiction and stress in adolescents. In M. al'Absi (Ed.), Stress and addiction: Biological and psychological mechanisms (pp. 249-262). Burlington, MA: Academic Press. http://dx.doi.org/10.1016/B978-012370632-4/50015-2

Taylor, S., \& Wald, J. (2003). Expectations and attribution in social anxiety disorder: diagnostic distinctions and relationship to general anxiety and depression. Cognitive Behavior Therapy, 32, 166-178. http://dx.doi.org.10.1080/16506070310020315

Vitelli, R. (2013). Staying in control-can believing we are in control of our health make us live longer. Retrieve from https://www.psychologytoday.com/blog/mediaspotlight/201310/staying-in-control.

Weiner, B. (1974). Achievement motivation as conceptualized by an attribution theorist. In B. Weiner (Ed.). Achievement motivation and attribution theory (pp. 95-120). Morristown, N.J.: General Learning Press. 
Weiner, B. (1986). An Attributional Theory of Motivation and Emotion. New York: SpringerVerlag.

Wallston, K. A., Wallston, B. S. Smith, S., \& Dobbins, C. J. (1987). Perceived control and health. Current Psychological Research and Reviews, 6, 5-25. http://dx.doi.org/10.1007/BF02686633

Yu, P., Su, S., \& Li, L. (2005). The relationships between college students' attributional style, self-efficacy and subjective well-being. Chinese Journal of Clinical Psychology, 13, 43-44. 